\title{
On the Talent-cultivating Mode of School-enterprise Cooperation from the Perspective of Innovation and Entrepreneurship
}

\author{
Dong Rui \\ School of Culture Communication \& Design, Zhejiang University of Finance \& Economics Dongfang College, Hangzhou, China \\ Email address: \\ dongxiaoyaya@126.com \\ To cite this article: \\ Dong Rui. On the Talent-cultivating Mode of School-enterprise Cooperation from the Perspective of Innovation and Entrepreneurship. \\ International Journal of Education, Culture and Society. Vol. 5, No. 3, 2020, pp. 45-52. doi: 10.11648/j.ijecs.20200503.12
}

Received: May 15, 2020; Accepted: May 25, 2020; Published: June 3, 2020

\begin{abstract}
Innovation and entrepreneurship activities are the primary focus of national development under the new normal of economy in China. Based on a detailed analysis of related policy documents, such as the Opinions on Deepening the Reform of Innovation and Entrepreneurship Education in Colleges and Universities by the General Office of the State Council of China, and the Outline of China's National Plan for Medium and Long-term Education Reform and Development (2010-2020), this article examines the background of the reform of innovation and entrepreneurship education and the current situation and existing problem of talent cultivation mode. Focusing upon the school-enterprise coordination in ordinary universities and colleges, it probes into the construction of "Innovation and Entrepreneurship" curriculum system, the overall arrangement of the rank of teachers and the innovation in practice in China. Through a careful investigation into the reform of talent-cultivating mode in practical education, the author aims to develop a "school-enterprise cooperation" talent-cultivating mode of school-enterprise cooperation which is multi-dimensional and progressive. In the process of exploring the perspective of professional education reform, perspective of learning, perspective of school-enterprise cooperation mode and perspective of social development, to achieve the seamless connection between talent training and social needs, thus promoting the development of social economy.
\end{abstract}

Keywords: Innovation and Entrepreneurship, School-Enterprise Cooperation, Curriculum System, Education Reform

\section{Introduction}

Recent years have witnessed a problem that China's higher education cannot meet the needs of economic development in our society. As innovation and entrepreneurship have become a mega trend for the development of the society, the State Council and the Ministry of Education of China have released a series of measures and outlines concerning the education reform, one of which is that science and technology have been a crucial support for improvement of social productivity and comprehensive national power and therefore overall national development must center upon these two factors, as is pointed out in an opinion to promote mass entrepreneurship and innovation. In 2015, China announced its Outline of China's National Plan for Medium and Long-term Education Reform and Development (2010-2020), stating the need to create a system of school-enterprise cooperation. In line with the outline, universities and colleges should adopt an open talent-cultivation system with flexible mechanisms, interlinked channels and diverse choices, and strengthen the cooperation between schools, between schools and enterprises, as well as between schools and research institutes. In the same year, the Ministry of Education issued an opinion to guide a number of local undergraduate institutions to transform themselves into applied colleges. Much emphasis has been put on the initiative to "deepen the reform of talent development programs and curriculum systems; facilitate the socioeconomic development and the advancement of industry technology as a driving force to promote the curriculum reform"; "innovate cultivation mode for application-oriented and technical skills-oriented talent, and establish talent-cultivation processes with the aim of improving practical skills". This guiding opinion has reinforced the strategic significance of mass entrepreneurship and innovation. 
It can be seen that in college education and teaching, the concept of innovation and entrepreneurship is getting more and more attention, and it becomes obvious how important school-enterprise cooperation is [1-6]. At present, the cultivation of innovative and entrepreneurial talents has been an important aspect to test the talent output of colleges and universities. Compared with Western developed countries, the establishment of innovation and entrepreneurship education curriculum system for college students in China is still at the initial stage. A lack of systemization in teaching approaches requires further explorations of the scientific path of school-enterprise cooperation. Domestic policies of mass entrepreneurship and innovation are booming currently, making education reform in innovation and entrepreneurship an important step and a breakthrough in facilitating comprehensive reform in higher education. It is necessary for school-enterprise cooperation, an important approach to train application-oriented talents in undergraduate institutions, to combine the practical teaching training goal and daily learning. This combination is of great benefit to a tighter connection between higher education, technology, economics and the society [7-8].

\section{Current Situations and Problems}

\subsection{Analysis of Current Situations}

\subsubsection{Talent Demand and Employment}

With the rapid economic development and the advent of big data era in China, there is an increasing demand for application-oriented innovative talents. However, official data show a remarkable conflict among employment, talent supply and talent demand. For one thing, despite a growing number of university graduates over the years, the employment figures turn out to be disappointing, with a decreasing tendency in some majors. For another, as reported by employers, there is a shortage of talents with entrepreneurial, innovative spirit, in spite of a large number of graduates and a diversity of choices in the labor market. From the perspective of talent output, such a conflict is associated with the traditional and unified talent cultivation mode which persists in China's educational practices until today. Along with the dramatic development of economy in the 21 st century, the standards for the society, enterprises and public institutions to select talents are constantly updated and modified. Some shortcomings of the talent-cultivating system in higher education have come to light as universities begin shifting their focus from theory teaching towards professional application. In particular, those shortcomings mainly lie in a lack of the cultivation mode for innovative and entrepreneurial talents. Guided by social needs, aiming at students' quality growth and future development, "coordination of industry and education to integrate and share high-quality educational resources, school-enterprise cooperation for mutual benefit and inter-industry development" should be considered as vital breakthroughs in school's talent training mode [9].
Today in a general trend toward community service and market orientation, schools should make it a top priority in the reform of talent-cultivating mode to further integrate education with industrial development and encourage school-business cooperation.

\subsubsection{The Establishment of University EE Curriculum System far from Satisfaction}

According to the U.S. Department of Labor, entrepreneurship education (EE) "seeks to prepare people, particularly youth, to be responsible, enterprising individuals who become entrepreneurs or entrepreneurial thinkers by immersing them in real life learning experiences where they can take risks, manage the results, and learn from the outcomes" [10]. This definition indicates that innovation and entrepreneurship education (IEE) is neither teaching of a course nor cultivation of a certain skill. Instead, it is concerned with comprehensive training and enhancement of talent quality. In an era of knowledge economy when "innovation steers the course to entrepreneurship and entrepreneurship boosts employment", what the society calls for is no longer technical experts or knowledgeable generalists but inter-disciplinary talents equipped with thinking ability, skills and creativity. As a result, the contents of talent cultivation in the ongoing IEE should cover not only intelligence and skill but ability and quality. Given this, the author believes IEE is a process of developing students' innovative consciousness and entrepreneurial ability and that the core of IEE is to help students learn how to combine innovative spirit with professional practice and to translate business ideas into social development. As to how to realize IEE in university teaching system, it is suggested that school-enterprise cooperation be the most workable solution.

On the basis of analysis and investigation, the author categorizes the teaching approaches to Chinese university students' IEE into three types. The first type is to add IEE to the classroom teaching of "University Students Career Guide" and "University Students Career Planning"[3]. The second type is to partially revise the original elective or required course module so that students need to get requested credits in entrepreneurship courses. The last type is for the independent entrepreneurship schools in universities to offer basic required courses on entrepreneurship to all students under the guidance of the "Basic Requirements for the Teaching of Entrepreneurship Education in Ordinary Undergraduate Schools (Trial)".

We can easily tell from the teaching approaches above that the ongoing IEE in most universities is basically independent from the original curriculum system. In other words, a systematic curriculum system which perfectly combines theory and practice has not come into being yet, and there is widespread homogenization of talent cultivation. Thus, in order to put IEE into practice and ensure further improvement and development, we still need to introduce enterprise resources actively, to promote teaching effectiveness, to correct problems in teaching staff's quantity, quality as well as structure based on collaborative effect brought by 
school-enterprise coordination mechanisms, and to explore, achieve and improve a shared long-term system for school-enterprise resources.

\subsection{Reflection on Problems}

\subsubsection{Incomplete Realization of the Core Value of IEE \& Weak Extensibility of the University Curriculum System}

The cultivation of innovative and entrepreneurial talents contains two aspects: innovation and entrepreneurship. Its objective is to boost the market competitiveness of high-end human capital and intellectual capital. When it comes to IEE in universities and colleges, the focus is upon the development of students' innovative quality and entrepreneurial ability. Also, schools are mainly responsible for cultivating the innovative spirit and practical ability of the students, so that students can master the way to learn and to develop, and improve social adaptability. From the perspective of the talent training objective, IEE should be a scientific and systematic reform project in teaching. In a bid to facilitate IEE, schools should consider industry-university-research-practice cooperation, and integrate the talent training objective of IEE into syllabus of general education courses and basic specialized courses. Efforts should be made to build a scientific and wide-ranging curriculum system for innovation and entrepreneurship, and to let the spirit of innovation and entrepreneurship permeate every level of higher education and teaching. Only in this way can we achieve value-added and efficient education rather than make a gesture of endeavor by offering more courses.

At present, universities in China are strengthening the inter-relations between various majors and intensifying training beyond the classroom. However, the current situation is characterized by a relative lack of systematic planning and effective coverage. The reasons are as follows. First of all, looking into the curriculum of most Chinese colleges and universities, we find most of the mature professional curriculum systems have been relatively systematic for many years, and teaching plans have been relatively complete as well. And in view of the difficulty of curriculum reform and people's inertia, it is no wonder that most universities choose to offer courses on the practie of innovation and entrepreneurship in the "second classroom". Furthermore, those who teach such courses are mainly university counsellors or teachers from the Entrepreneurship School, the majority of whom have no business experience and therefore, are unable to effectively guide students to transform theoretical knowledge into practical skills from a practical perspective. This kind of paper-based teaching cannot help cultivate students' innovative awareness and sensitivity over entrepreneurship in an effective way. Consequently, students cannot truly grasp the essence of IEE. Although the paper-based teaching works to some extent, it is no more than additional courses in classroom for the sake of IEE since there's no scientific teaching systems of innovation and entrepreneurship.

The core value of IEE manifests itself in systematic and value-added educational extension. At the beginning of designing an IEE curriculum system, universities and colleges should take it as an extension of the original education curriculum system, rather than simply a new independent part which has a different curriculum credit system. Schools need to combine theory with practical teaching properly and develop a multi-dimensional educational teaching model in which innovative practice and business ideas are connected to each other. They should also insist in the teaching philosophy of "double track". That is to say, knowledge learning reflects the teaching process, and hands-on practice reflects the teaching results. To sum up, IEE is supposed to be value-added education of knowledge and skills instead of added procedures in classroom teaching.

\subsubsection{Limited Practical Application of IEE \& Narrow Coverage of Talent Cultivation}

The concept of innovation education was first proposed by the famous American economist Joseph Schumpeter. This concept illuminates the relationship between thought and economic development, and emphasizes that the purpose of innovation is to make enterprises better adapt to the development of economic society [11]. So, the most direct way to judge the success of IEE is to check how society and enterprises react to the talent output. Given this, we should deepen coordination between schools and enterprises and explore an efficient talent-cultivating mode in the process of systematically constructing the teaching system. However, currently, most universities and colleges in China refer to the number of students participating in the entrepreneurship competitions and the number of entrepreneurs after graduation to evaluate the effectiveness of innovation and entrepreneurship teaching. And teachers and students focus primarily on statistics and competition performance. As a consequence, much emphasis is placed on the training of excellent students. Such "elite" training has narrowed the coverage of mass education. The practical training in IEE should be an in-depth coverage of general education courses, specialized courses, social practice, etc., rather than repeat the original "elite" teaching.

As mentioned above, it is found that due to the weak foundation of China's IEE development, the practical teaching system in universities and colleges has not been perfect yet, and how to build teaching teams and design curriculum systems needs to be further explored. The social development demands that we "encourage entrepreneurship to create more employment opportunities" and that we "enhance China's capacity for independent innovation and make China an innovative country". In accordance with these demands, we should re-examine the essence and value of IEE and efficiently advance the teaching reform. The school-enterprise cooperation should be integrated into the traditional disciplinary instruction and learning by practice in the "second classroom". In doing so, we hope to stimulate market competition and promote the scientific development of IEE in universities. 


\section{Strategies for Constructing School-Enterprise Coordination Mechanisms}

\subsection{To Establish Scientific, Multi-Dimensional Practical Curriculum System and Develop a Progressive IEE Teaching Mode}

The idea of IEE originated from the United States. Here, we draw on the goal of creating "T-shaped" individuals proposed by Professor Tom Byers at Stanford University in the United States who is the founder of the Stanford Technology Ventures Program (STVP). The so-called "T-shaped" individuals are people with a breadth of knowledge across many skills and a great depth of knowledge in a certain discipline. Across the top of the $\mathrm{T}$ are a knowledge of design, entrepreneurship, innovation and leadership [12]. This goal, once again, illustrates a shared understanding of IEE by the international community that IEE does not mean to finish a course but to cultivate and effectively output talents' comprehensive ability. Currently, the most direct way to judge the quality of talent output is to check the students' employment rate and if the talents are recognized by the society.

The education reform has witnessed a trend toward industry-university-research-practice cooperation and school-enterprise coordination. A common problem faced with most universities in China is that the talent-cultivating goal is too broad and that requirements concerning professional industry knowledge and ability are imprecise. To solve the problem, we'd better start from school-enterprise coordination and integrate the core value of IEE, i.e. value-added education based on the original courses, into the existing curriculum system. We should set professional talent-cultivating objectives combined with industry development plans, according to the syllabus formulated by the Ministry of Education, by reference to job requirements of enterprises in the industry, technical specifications, enterprise project management mechanisms and operational methods. And those objectives have to be further selected and adjusted to the actual situations of each school. Furthermore, it is suggested to devise hierarchical teaching with associated degrees of difficulty. It means that the ability-training courses with different objectives are integrated to the talent-cultivating system of school-enterprise cooperation, in order to meet the development needs of students with diverse interests in different disciplines and majors to the greatest extent. What's more, we should also establish a set of multiple and innovative talent development programs which conform to the knowledge structure of professional theory and meet the talent demand in society at the same time.

With regard to the four-year hierarchical teaching system in undergraduate schools, the author conceives a progressive and multi-dimensional curriculum system of "school-enterprise cooperation" based on the analysis of online and offline questionnaires answered by students and graduates. The focus of attention is pointed out at different stages when the author constructs the progressive teaching framework for the sake of cultivating students' thinking ability and practical ability. Detailed information about the course distribution is shown in the table below (Table 1).

Table 1. A Progressive and Multi-Dimensional Curriculum System of "School-Enterprise Cooperation".

\begin{tabular}{|c|c|c|c|c|}
\hline \multicolumn{5}{|c|}{ A Progressive and Multi-Dimensional Curriculum System of "School-Enterprise Cooperation" } \\
\hline & 1st Year & 2nd Year & 3rd Year & 4th Year \\
\hline Requirement & $\begin{array}{l}\text { basic knowledge of the subject } \\
+ \text { cognitive practice }\end{array}$ & $\begin{array}{l}\text { professional core } \\
+ \text { professional practice }\end{array}$ & $\begin{array}{l}\text { professional interests } \\
+ \text { comprehensive practice }\end{array}$ & $\begin{array}{l}\text { Mentor-made courses } \\
+ \text { real-life practice }\end{array}$ \\
\hline Course & basic courses & $\begin{array}{l}\text { basic courses } \\
\text { professional courses }\end{array}$ & $\begin{array}{l}\text { professional courses } \\
\text { practice courses }\end{array}$ & $\begin{array}{l}\text { comprehensive practice } \\
\text { graduation project }\end{array}$ \\
\hline \multirow{2}{*}{$\begin{array}{l}\text { Teaching } \\
\text { Practice }\end{array}$} & $\begin{array}{l}\text { to introduce the culture in } \\
\text { enterprises and industries }\end{array}$ & $\begin{array}{l}\text { to let corporate mentors and } \\
\text { industry specialists to teach in } \\
\text { the classroom }\end{array}$ & $\begin{array}{l}\text { to introduce practice projects } \\
\text { into the classroom }\end{array}$ & \multirow{2}{*}{$\begin{array}{l}\text { innovation \& } \\
\text { entrepreneurship training } \\
\text { innovation-and-entreprene } \\
\text { urship-oriented } \\
\text { comprehensive practice }\end{array}$} \\
\hline & lecture on industries & practice in professional courses & $\begin{array}{l}\text { innovation-oriented } \\
\text { professional practice }\end{array}$ & \\
\hline $\begin{array}{l}\text { Teaching } \\
\text { Objective }\end{array}$ & $\begin{array}{l}\text { industry-specific general education } \\
\text { combined with specialized skill } \\
\text { education }\end{array}$ & $\begin{array}{l}\text { core knowledge \& skills of the } \\
\text { profession combined with } \\
\text { teachers' demand for practice }\end{array}$ & $\begin{array}{l}\text { cultivation of core } \\
\text { professional competence } \\
\text { combined with enterprises' } \\
\text { innovative practice }\end{array}$ & $\begin{array}{l}\text { school-enterprise dual } \\
\text { mentoring combined with } \\
\text { talent output }\end{array}$ \\
\hline
\end{tabular}

For example, the school curriculum can be arranged into a hierarchy with different capacity requirements, insertion methods of teaching practice, and teaching objectives in the four separate years. In the meantime, the concept of progressive school-enterprise cooperation in practical teaching can be realized in the curriculum system. The capacity requirements in the hierarchy can be subdivided according to how well students fit into the degrees of difficulty of courses. For instance, since the first year is a transition period for students, freshmen should be required to master the basic knowledge of the subject and have a certain practical understanding of the major. Therefore, at this stage, the practical teaching is mainly to deliver lessons to introduce the culture in enterprises and industries, so as to achieve the teaching goal of combining industry-specific general education and specialized skill education. In the second year, students have enough knowledge and skills to learn the core lessons of the profession. So, at this stage, we should teach both core knowledge of the profession and related skills, and let industry leaders, business leaders, experts and professors to 
teach in the classroom. In virtue of the practical training through business practice projects in the teaching process, students will enhance their professional practical ability and be prepared for the subsequent IEE. Moving onto the third year, we will give students guidance in terms of professional preferences. At this stage, students will identify their professional interests for in-depth learning. In order to cultivate students' core professional competence, we will equip students with creativity and comprehensive ability in practical activities through business projects. In the fourth year, students have fewer courses. We plan to conduct dual-mentor guidance, create opportunities of practice by using social resources and corporate resources, and train students to be innovative and entrepreneurial. By this means, students can better adapt to the society.

The phased and focused curriculum system is designed to achieve four teaching objectives: specialized industry general education combined with specialized skill education in the first year, core knowledge $\&$ skills of the profession combined with teachers' demand for practice in the second year, cultivation of core professional competence combined with enterprises' innovative practice in the third year, and school-enterprise dual mentoring combined with talent output in the fourth year. The overall goal is to achieve multi-dimensional practice and teaching, to progressively cultivate the innovation and entrepreneurship capabilities, to realize school-enterprise cooperation and innovation-entrepreneurship integration in a meaningful manner. Such a training system has two advantages. On the one hand, we can keep the original systemic professional curriculum system of each major. On the other hand, in the process of school-enterprise cooperation, we can formulate the professional talent-cultivating objectives scientifically, efficiently and precisely, and improve students' professional ability quickly. As a result, our talent training will achieve professionalism, systematism and sociality from a horizontal perspective, and achieve progress at the levels of technology, management and creativity one by one from a vertical perspective.

\subsection{To Build a Hierarchical Teaching Team, Diversify Teaching Forms, and Make Enterprise Matching Precise}

The core competency of a university depends on the rational construction of the faculty, while the quality of IEE of college students depends largely on the construction of an innovative teaching team. At present, most university teachers in China are engaged in teaching immediately after graduation. As highly educated talents, they are good at theoretical research, yet they lack experience in social and corporate practice. Therefore, the lack of teachers with adequate knowledge structures and hands-on experience partly accounts for the fact that teaching effectiveness of IEE in Chinese universities is generally unsatisfactory and the students' practical ability hasn't been improved significantly.

Stanford University has been recognized as a pioneer in the field of entrepreneurship education. Stanford's approach to entrepreneurship education is to bring together "cutting-edge theory and real-world expertise" in the classroom. Accordingly, Stanford has designed a variety of methods of entrepreneurship education, such as team teaching, workshop teaching and practical teaching [10]. In order to meet the demands of diversified teaching methods, Stanford has a wide range of entrepreneurship teachers from university professors to consulting faculty consisting of local entrepreneurs, executives of famous technology companies and investors in venture capital firms [1].

Learning from Stanford, we can incorporate the idea of "teaching-learning-doing integration" into the practical teaching of "school-enterprise cooperation", and diversify the faculty by building a team of professionals ranging from industry experts, engineers in enterprises to technicians. In the teaching process, the school can adopt a "double-track" teaching mode with a teaching team dominated by on-campus teaching staff and supplemented by part-time teachers from enterprises. The university teachers can carry out gradient division of teaching tasks according to the tree diagram of the curriculum system, while the part-time teachers from enterprises can help enrich the teaching contents and diversify the teaching modes through classroom teaching, lectures, etc. In this way, we attempt to create a practice-oriented, mixed classroom teaching mode featuring both diversity and fun, and to build a "dual-teacher" teaching team containing both full-time and part-time staff members. At present, many universities have taken these measures already. However, the lack of top-level system planning and curriculum module design in the course construction has led to some problems, like the random arrangement of courses and the fragmentation of teaching objectives.

Hence, in order to improve the curriculum system of "school-enterprise cooperation" in universities and colleges, we should strive for the organic integration of professional education and practice-oriented education, and try our best to achieve the coordination between schools and enterprises. To be more specific, we can add value to the compulsory courses and fit application-oriented teaching tasks into the class schedule.

Table 2. Analysis of Course Modules and Teaching Forms.

\begin{tabular}{|c|c|c|c|c|}
\hline \multicolumn{5}{|c|}{ Course Modules and Teaching Forms } \\
\hline & Module I & Modul II & Module III & Module IV \\
\hline $\begin{array}{l}\text { Type of } \\
\text { Course }\end{array}$ & theory-oriented course & $\begin{array}{l}\text { theory-and-practice-oriented } \\
\text { course }\end{array}$ & $\begin{array}{l}\text { practice-and-innovation-oriented } \\
\text { course }\end{array}$ & course for extension \\
\hline $\begin{array}{l}\text { Teaching } \\
\text { Team }\end{array}$ & $\begin{array}{l}\text { teachers of basic courses } \\
\text { +teachers of professional } \\
\text { courses }\end{array}$ & $\begin{array}{l}\text { teachers of basic courses } \\
+ \text { corporate mentors } \\
+ \text { teachers of professional } \\
\text { courses }\end{array}$ & $\begin{array}{l}\text { teachers of professional courses }+ \\
\text { corporate mentors } \\
\text { +industry experts }\end{array}$ & $\begin{array}{l}\text { teachers of professional courses } \\
\text { +industry experts } \\
\text { +corporate mentors }\end{array}$ \\
\hline
\end{tabular}




\begin{tabular}{|c|c|c|c|c|}
\hline \multicolumn{5}{|c|}{ Course Modules and Teaching Forms } \\
\hline & Module I & Modul II & Module III & Module IV \\
\hline $\begin{array}{l}\text { Content of } \\
\text { Course }\end{array}$ & $\begin{array}{l}\text { theory +introduction of } \\
\text { industry knowledge }\end{array}$ & $\begin{array}{l}\text { Theory + practice } \\
\text { +professional divergent } \\
\text { thinking }\end{array}$ & $\begin{array}{l}\text { theory }+ \text { practice }+ \text { introduction of } \\
\text { innovation projects }\end{array}$ & $\begin{array}{l}\text { theory }+ \text { practice }+ \\
\text { introduction of entrepreneurship } \\
\text { projects }\end{array}$ \\
\hline $\begin{array}{l}\text { Form of } \\
\text { Teaching }\end{array}$ & $\begin{array}{l}\text { early insertion of } \\
\text { professional projects }\end{array}$ & project training & $\begin{array}{l}\text { project training } \\
+ \text { real-life practice }\end{array}$ & $\begin{array}{l}\text { real-life practice }+ \text { innovation } \\
\text { and entrepreneurship training }\end{array}$ \\
\hline
\end{tabular}

Based on the above analysis, we can start with refining the existing professional education courses and then classify them into different categories, including theory, theory combined with practice, theme practice, and extension. After a clear division of the nature of the courses, we can assign different teachers to different types of courses. The teaching content and teaching form also need further discussion and reflection. In doing so, we are aimed at achieving scientific control both at the macro level and at the micro level, so as to probe into a diversified and interesting classroom teaching mode (see Table 2). What is of the utmost importance about this scenario is that, based on the nature of the courses and the division of the modules, we can classify the partner companies and match different companies and experts with our courses precisely. The scenario improves students' learning efficiency and maximize the value of partner companies. It helps, on one hand, companies with talent acquisition. On the other hand, it is conducive to the subsequent in-depth training and the cultivation of specialized individuals.

\subsection{To Establish Practice-Oriented Innovation Education with "Double-Classroom Integration and School-Enterprise Cooperation” Mode}

Today, we are confronted with several problems, including limited job opportunities, the large number of college graduates and low employment rate. Given this, we can deepen teaching reform through "double-classroom integration" in the school-enterprise cooperation, based on the IEE model. The so-called "double-classroom integration" refers to the combination of general practice-oriented innovation education for all students and practice-oriented small business education based on elective courses and the second classroom activities. The former helps students to master innovative knowledge and develop entrepreneurial awareness via general education courses or required courses, and therefore requires a wide coverage of "school-enterprise cooperation". By contrast, the latter allows students to choose a small business curriculum that they like in the "second classroom". The curriculum they choose can offer in-depth teaching. Moreover, teachers can guide and encourage students to start a business after graduation in accordance with their own interests, hobbies and traits.

The first type of classroom for "general practice-oriented innovation education" is closely linked to the construction of the basic teaching system and teaching form as mentioned previously. Within the cultivation mode of "school-enterprise coordination", universities and colleges can build a scientific and multi-dimensional general education curriculum system, incorporating students' practical training of innovation and entrepreneurship into the talent development programs of the "first classroom". Through on-campus mixed curriculum teaching, enterprise projects inserted in classrooms and other forms of teaching reform, we can cover professional teaching from the perspective of breadth, enhancing students' professional abilities, and boost students' spirit of innovation and entrepreneurship from the perspective of depth. Furthermore, a win-win outcome is expected to be produced via the mutual transformation of "practical achievements" and "research achievements".

As for the second type of classroom for "practice-oriented small business education" based on elective courses and the second classroom activities, universities, together with partner companies, can build student pioneer parks, project incubators and specialized internship bases so as to enable students to gain personal experience with business practice. It is worth mentioning that, unlike the "first classroom" in which teachers play a dominant role, the "second classroom" stresses the leading role of students. Thus, in the "second classroom", we need to motivate the student union and various associations to organize college students' innovation and entrepreneurship competitions and other various professional competitions, creating a strong atmosphere of practice and innovation in universities.

In addition to learning from successful cases of excellent universities at home and abroad, we should also take China's national conditions and characteristics of Chinese students into consideration when developing programs and competitions. The goal of China's IEE is to cultivate "talents with innovative spirit, entrepreneurial ability and market competitiveness". To this end, we should relate students' motivation for innovation and entrepreneurship to the "school-enterprise coordination" and the talent requirements in different industries and majors. We should encourage students to participate in competitions and explore a participation mode featuring "multiple dimensions and diversified forms of a wider range", thereby enabling most students to have the opportunity to choose and attend competitions. There is a variety of competitions in China, such as school-level college students business planning contests, college students' innovation training projects by the provincial Department of Education, and the National College Students "Challenge Cup" Competitions. And we can increase the influence and coverage of those competitions through activities by the student union and other organizations alike. With the help of competitions, students can have a training platform to enhance their competence and make achievements.

In conclusion, the business projects introduced into the first classroom for "general practice-oriented innovation education", the major-specific "enterprise and industry" 
contests, competitions and practical activities of "double-classroom integration" in the second classroom constitute almost all the innovative practical activities that students can take part in in universities. In skill competitions held by schools, partner companies can be invited to be judges, which can bring three benefits. Firstly, it can strengthen students' consciousness of social competition and help to standardize the norms in enterprises and industries. Secondly, schools can show the students' strengths to the enterprises and examine the teaching level and faculty quality in different majors. Meanwhile, the performance of students and the competition results can become important criteria to decide which business projects will be selected to move into student pioneer parks, thereby laying a foundation for future careers. In brief, the ultimate purpose is to promote learning and training via competitions.

\subsection{To Set Scientific Criteria and Establish a Standardized Assessment System}

With the development of society, school-enterprise cooperation is no longer simply technical support or commissioned talent training. We ought to set scientific criteria and establish a standardized assessment system so as to shift the focus of talent cultivation from theory to practice and equip students with theoretical knowledge, innovative awareness and entrepreneurial ability.

In China, IEE has a relatively short history. The school-enterprise coordination in IEE is accompanied by the failure to create a robust assessment system and uniform criteria for talents. There are three types of assessment in the process of school-enterprise cooperation. The first type fits into basic courses in the first year and can be regarded as supervision and extension of the learning process. In this type, experts are merely engaged in courses and don't give scores [13]. The school-enterprise cooperation activities can be carried out by inviting experts to teach in classroom or offering a series of lectures on industry. And the homework should not be too difficult because the basic courses have a wide coverage of teaching methods, a large number of targeted students and a low level of difficulty. The teaching of these courses is aimed at helping students with a basic understanding of profession and industry. So, it is advised students write reports after courses and that experts not give scores. The second type of assessment means that the corporate mentors not only teach in the classroom but also give scores. It fits into courses in the second year and the third year. Sophomore and junior students start learning professional core lessons. They have mastered some basic professional knowledge and are able to attend comprehensive training projects with the assistance of mentors. Therefore, programs can be introduced into classroom at this stage. It is suggested that the score given by the mentor account for $30 \%-50 \%$ of the total according to circumstances and that students' course score be the sum of grades they get in regular courses on theoretical knowledge and courses of comprehensive practice. This assessment system will assess students' ability of transforming theoretical knowledge into practical competence and vice versa, and will evaluate their social competitiveness as well. The third is for experts to be in charge of guidance and assessment throughout the courses. It fits into senior students who participate in real-life projects whilst they are engaged in graduation project and internship. Projects and service are combined in this process. The main goal is to stimulate students' innovative entrepreneurial ability and practical ability.

This "standardized" assessment method, on the one hand, provides guidance and inspiration for students' future employment; on the other hand, it is also a powerful tool to further promote school-enterprise cooperation. However, the "standardized" assessment method should not be a unified standard that is followed indiscriminately. All schools should create a useful assessment system of their own according to the actual situations. The reform aims to integrate industry standards and norms into teaching. So, universities and colleges can select courses for a pilot reform and try to explore the evaluation criteria suitable for each major.

\section{Aims and Results of the Progressive Talent-Cultivating Mode Reform of "School-Enterprise Coordination"}

\subsection{To Discover Defects and Deepen Reform from the Perspective of Professional Education Reform}

By constructing a talent training system of "school-enterprise coordination", we can find out defects in terms of the school's talent training objectives from the perspective of social needs. This is helpful for universities to optimize curriculum systems and talent training standards. In an effort to carry out teaching reform and curriculum reform efficiently, problems including a small coverage of participants, a low level of curriculum and attention in economic effect but social effect should be solved. In a talent training system which is multi-dimensional and progressive, students can make the most of disciplinary knowledge combined with professional skills, while teachers can achieve a combination of theoretical teaching and special practice. Moreover, companies can relate assessment to industry standards. On the whole, the teaching process, against the backdrop of IEE, is expected to be improved.

\subsection{To Achieve Application of Knowledge and Efficient Output from the Perspective of Learning}

The "school-enterprise coordination" can ensure a combination of learning requirements and professional norms throughout the learning process. Talent training can be based on the industry-university-research-practice cooperation, in the forms of theoretical study, professional innovation, introduction of industry culture, etc. While taking part in projects, students can consolidate what they have learned and improve practical skills. In this way, professional disciplinary strength promotes students' innovation and entrepreneurship practice [14], making it possible that the universities' talent 
output meets the needs of the society.

\subsection{To Maximize the Teaching Effect from the Perspective of School-Enterprise Cooperation Mode}

The school-enterprise coordination requires a shift from single-dimensional cooperation to cooperation with a wide systemic coverage. Meanwhile, it should be long-term cooperation at multiple levels and stages. This will help redress the imbalance between talent supply and talent demand. On the part of enterprises, in-depth collaboration with schools not only brings talents but provides schools with innovative ideas regarding IEE. So, it is a win-win outcome with maximum benefits.

\subsection{To Achieve Accurate Matching of Talent Output from the Perspective of Social Development}

The report at the 19th National Congress of the Communist Party of China (CPC) has clearly pointed out that education is a key factor for the sustainable development of the society. In the future college education system, we need to focus on the implementation of the school-enterprise cooperation, and commit ourselves to helping students to "Enter the Society" as required by the "Five Enterings" education. Through the cooperation among students, schools and local leading enterprises or industries, the innovative research achievements based on the "industry-university-research integration" can be a powerful driving force for the modernization of local economy. Besides, the cultivation of college talents will be promoted by the practical teaching of school-enterprise cooperation, and the regional services and social development will be promoted by the output of high-quality talents.

\section{Conclusion}

The Innovative and entrepreneurial ability is the core competence in social development in the new era [15]. It is of great significance to carry out school-enterprise cooperation within the university education system. By adopting the talent-training mode of "school-enterprise coordination", we can cultivate and improve the students' ability to innovate and start businesses. A virtuous circle will be generated in which the implementation of students' tasks, teachers' social services, schools' educational reform, corporate expansion and growth can promote each other. Additionally, the college education will be closely linked to social and regional development; the two are coordinated and indivisible.

\section{Acknowledgements}

This work is supported by two programs in Zhejiang University of Finance \& Economics Dongfang College: (1) a Major Program of the Key Higher Education Teaching Reform Project, Cooperated Industry-University-Research
Application: Studies on Progressive Talent Training Mode (NO.: 2019JK03); (2) a Major Program of Special Design: Exploration and Practice of Practical Teaching. (NO.: 2019JK46).

\section{References}

[1] Dong Yanqing, Xu Jiajia, Yang Sha, Zhong Liangtao: Analysis on the Current Status and Strategy of College Students' Innovation and Entrepreneurship Practice [J], 2018. 04: 130-131.

[2] Ma Hui: Research on Developmental Problems of Enterprise Science and Technology Business Incubator [D], 2017.05.

[3] Meng Qingnan: On the Construction of the Entrepreneurship Education Curriculum System in Colleges [J], 2017. 06: $149-151$.

[4] Yi Debin, Song Xiaohua: The Building of School-Enterprise Cooperation Model Based on Training of Innovative and Entrepreneurial Talents [J], 2019. 09: 44-46.

[5] Peng Xumei: Research on the Rise and Development of Entrepreneurial University [D], 2008. 04.

[6] Hao Jie, Wu Aihua, Hou Yongfeng: Construction and Enlightenment of the Innovation and Entrepreneurship Education System in America, 2016. 02: 8-12.

[7] Qiao Yin, Li Yunfang: Reform and Innovation of the Teaching System in Innovation and Entrepreneurship Practice [J], 2020. 02: 175 .

[8] Wang Youmei: Review on the Theoretical Thinking of Current Maker Education Practice in Chinese Universities [J], 2017. 04: 20-31.

[9] Wang Xiaohui: Thoughts on Talent Training Mode for Environmental Design Major in Phased " $2+2$ " Higher Education from the Perspective of Innovation and Entrepreneurship [J], 2019. 06: 130-131.

[10] Zhong Xiaobin: A Study on Entrepreneurship Education at Stanford University [D], 2013. 06.

[11] Chen Yifei, Fu Lieming, Wang Zhaoye: Optimization Strategies to Manage Application-Oriented Undergraduate Schools from the Perspective of Innovation Education [J], 2019. 10: 26-28.

[12] Sun Lisha, Yan Jun: The Mechanism and Mode of Internationalization of Fist- Class Higher Education in the World [J], 2014. 10: 1-3.

[13] Zheng Guiyu: Reform and Research on Progressive Model of School-Enterprise Cooperation for Design Education: Taking Environment Art Design as an Example [J], 2014. 10: 120-121.

[14] Ye Lan: Research on the Construction of Innovation and Entrepreneurship Curriculum System in Universities [J], 2019. 21: 61-63.

[15] Wang Xiaoyan: Research on Long-term Training Mechanism of Innovation and Entrepreneurship Ability Based on School-Enterprise Cooperation [J], 2019. 10: 171-172. 